Zeszyty Naukowe Szkoły Głównej Gospodarstwa Wiejskiego w Warszawie Problemy Rolnictwa Światowego tom 17 (XXXII), zeszyt 1, 2017: 142-151

DOI: $10.22630 /$ PRS.2017.17.1.13

Robert Pietrzykowski $^{1}$

Szkoła Główna Gospodarstwa Wiejskiego w Warszawie

\title{
Zróżnicowanie dochodów gospodarstw rolniczych państw Unii Europejskiej - ujęcie czasowo-przestrzenne
}

\section{Income Differentials of Agricultural Farms EU Countries; Spatial-Temporarily Approach}

\begin{abstract}
Synopsis. Celem pracy było przedstawienie zmian w dochodach uzyskiwanych przez rolników w państwach należących do Unii Europejskiej z uwzględnieniem dodatkowych czynników jakimi są czas i lokalizacja w przestrzeni. W przeprowadzonych analizach zwrócono szczególną uwagę na państwa, które wstapiły do Unii Europejskiej po roku 2004 (UE-11: Estonia, Czechy, Łotwa, Litwa, Polska, Słowacja, Słowenia, Węgry, Bułgaria, Rumunia i Chorwacja). Ze względu na makroekonomiczny charakter badań wykorzystano Rachunki Ekonomiczne dla Rolnictwa (RER). W pracy wykorzystano współczynnik autokorelacji Morana. W wyniku przeprowadzonych analiz stwierdzono występowanie dodatniej autokorelacji przestrzennej co potwierdziło występowanie klastrów dla państw wchodzących w skład Unii Europejskiej.
\end{abstract}

Słowa kluczowe: dochód rolniczy, analiza czasowo-przestrzenna, współczynnik Morana

\begin{abstract}
The aim of the study was to show changes in income received by farmers in countries belonging to the European Union having regard to the factors which are time and location in space. In the performed analysis, we pay special attention to the countries which joined the EU after 2004 (UE-11: Estonia, Czech Republic, Latvia, Lithuania, Poland, Slovakia, Slovenia, Hungary, Bulgaria, Romania and Croatia). The study used data on farms, which are generally in the Eurostat database. Because of the macroeconomic nature of the research used in Economic Accounts for Agriculture (RER). The study used autocorrelation coefficient of Moran. The analyzes were found positive spatial autocorrelation in the period 2004-2013 which confirmed the existence of clusters for the countries belonging to the European Union.
\end{abstract}

Key words: agricultural income, spatial-temporarily analysis, the coefficient of Moran

\section{Wprowadzenie}

Realne dochody gospodarstw rolniczych w Unii Europejskiej wzrosły od roku 1980 średnio ponad $40 \%$. Uważa się, że na wzrost dochodów gospodarstw rolniczych miały wpływ następujące czynniki: poprawa wydajności produkcji, zmiany w strukturze agrarnej, powiększanie gospodarstw rolniczych oraz wspólna polityka rolna (WPR) (Biczykowski, 2013; Pietrzykowski, 2016). Ten ostatni czynnik jest szczególnie widoczny dla państw, które zostały przyjęte do Unii Europejskiej po roku 2004. Z prowadzonych badań (Pietrzykowski, 2016) wynika, że zmiany zachodzące w dochodach gospodarstw rolniczych są powodowane przede wszystkim przez subwencje. Rolnictwo w państwach UE-11 charakteryzuje się relatywnie niską wydajnością produkcji przez co obserwuje się

${ }^{1}$ dr inż., Katedra Ekonomiki Rolnictwa i Międzynarodowych Stosunków Gospodarczych SGGW w Warszawie, 02-787 Warszawa, e-mail: robert pietrzykowski@sggw.pl 
relatywnie duże zróżnicowanie dochodów. Pewne jest jednak, że integracja nowych państw z UE ma pozytywny wpływ na dochodowość gospodarstw rolniczych i wyrównywanie różnic pomiędzy państwami (Pietrzykowski, 2016). Należy jednak zauważyć, że przyjęcie programów WPR chociaż przyczyniało się do wzrostu dochodu to ograniczenia narzucane przez Unię Europejską w pewnym sensie są czynnikiem destymulującym dochody gospodarstw rolniczych. Obserwowane zmiany zachodzą zarówno w czasie jak i przestrzeni. Jak zauważył Czyżewski (Czyżewski, 2008) dochody gospodarstw rolniczych w długim okresie czasu mają raczej tendencję spadkową. Wynika to z zachowań popytu i podaży w sektorze rolniczym. Zatem oprócz wymienionych wcześniej wyników powodujących zmiany w dochodach gospodarstw rolniczych należy zauważyć, że kolejnym czynnikiem różnicującym dochód jest czas i położenie (przestrzeń).

Celem pracy było przedstawienie zmian w dochodach uzyskiwanych przez rolników w państwach należących do Unii Europejskiej z uwzględnieniem dodatkowych czynników jakimi są czas i lokalizacja w przestrzeni. Makroekonomiczny charakter prowadzonych badań jest bardzo ważny ze względu na kształtowanie polityki rolnej, ale również na określenie zmian rozwojowych na poziomie regionalnym. Natomiast uwzględnienie w zachodzących procesach ekonomicznych czasu i przestrzeni wzbogaca informacje i daje lepszy ogląd rzeczywistości gospodarczej. W przeprowadzonych analizach zwrócono szczególną uwagę na państwa, które wstapiły do Unii Europejskiej po roku 2004 (UE-11: Estonia, Czechy, Łotwa, Litwa, Polska, Słowacja, Słowenia, Węgry, Bułgaria, Rumunia i Chorwacja).

\section{Czas i przestrzeń w ekonomii}

Odniesienie do asymetrii i nieodwracalności czasu jako zjawiska w ekonomii można znaleźć w neoklasycznej teorii równowagi ogólnej, austriackiej szkole psychologicznej, ekonomii postkeynesowskiej, ekonomii ewolucyjnej, austriackiej szkole subiektywnej i ekonomii marksistowskiej. W teorii ekonomii bardzo często starano się ignorować czas. Zjawiska ekonomiczne występowały w taki sposób jakby odbywały się poza czasem. Nie wszyscy ekonomiści akceptowali takie podejście. Uważali oni, że czas jest nierozerwalnym elementem, który wpływa na procesy ekonomiczne i jako taki powinien być traktowany jako zmienna deterministyczna. Ekonomiści tego nurtu uważali, że możliwe jest również uwzględnienie czasu jako elementu powodującego logiczne następstwo zdarzeń. W takim przypadku powinniśmy określić horyzont czasowy. A zatem należy stwierdzić, że modelowanie ekonomiczne nie może być pozbawione elementu jakim jest czas. W modelach ekonomicznych czas traktowany jest jako zmienna dyskretna lub ciągła, co nie implikuje określenia czasu logicznego czy rzeczywistego. Taki sposób powoduje jednak, że w modelach ekonomicznych ujęcie skokowe czasu przybliża nas do praktyki, a ujęcie ciaggłe jest wykorzystywane $\mathrm{w}$ analizie teoretycznej. Zagadnienie czasu w teorii ekonomii jest bardzo rozbudowane i wiąże się z rozważaniami nad czasem, który jest asymetryczny i nieodwracalny. A zatem czas może być traktowany jako cecha, zjawisko lub jako czwarty wymiar. Każdy sposób wyodrębnienia czasu wiąże ze sobą pytania i problemy, które związane są z odpowiednim podejściem do procesów ekonomicznym (Czaja, 2011; Faber, 1986; Zamagni i Agliardi, 2005).

Zagadnienie przestrzeni, czyli lokalizacji w ekonomii podobnie jak ujęcie czasu nie było uwzględniane przez ekonomistów klasycznych i neoklasycznych. Współzależności 


\section{R. Pietrzykowski}

gospodarcze rozważane w ekonomii najpierw zdynamizowano wprowadzając efekt czasu, a w późniejszych okresach wprowadzono efekt przestrzenny. Wprowadzenie czynnika czasu było o wiele prostsze i łatwiejsze. Jeżeli chodzi o czynnik związany z przestrzenią wprowadzenie go do ekonomii wiązało się $\mathrm{z}$ wieloma problemami, a mianowicie z zauważeniem zróżnicowania ze względu na postrzeganie środowiska naturalnego i jego przekształceń spowodowanych przez człowieka. Twierdzenia w teorii ekonomii klasycznej, które pomijały wymiar przestrzenny należy uznać za niepełne i przedstawiające rzeczywistość $\mathrm{w}$ zbytnim uproszczeniu. Jeżeli będziemy rozważali wytwarzanie i podział dochodów w państwie, nie uwzględniając lokalizacji i podziału na regiony bogate i biedne, to uzyskamy opis mijający się z rzeczywistością. Podobnie, jeżeli weźmiemy pod uwage innowacje i ich rolę we wzroście gospodarczym, jeśli pominiemy zróżnicowanie regionalne ograniczymy tym samym jakość wyjaśnienia zachodzących procesów. Rozważając efektywność inwestycji nie będziemy w stanie uzyskać pełnego wyjaśnienia zachodzących zmian, jeśli nie uwzględnimy ich umiejscowienia w przestrzeni czyli pominiemy korzyści koncentracji. Analizując problemy dotyczące wahań gospodarczych, powinniśmy obejmować skutki przenoszenia wahań z regionu do regionu, aby uzyskać większą szansę na oszacowanie jakości tego procesu. Podobnych przykładów można by mnożyć. Dlatego ważnym krokiem na drodze rozwoju ekonomii przestrzennej i zauważenia, że procesy gospodarcze odbywają się oprócz czasu również w przestrzeni były badania prowadzone przez ekonomistów niemieckich. Rozwój ekonomii przestrzennej należy przypisać Johannowi Heinrichowi von Thünen, który w 1826 roku opracował teorię stref rolniczych, określaną jako teorię kręgów. W swojej pracy „Der isolierte Staat” Thünen sformułował prawo mówiące, że w miarę oddalania się od punktu centralnego, którym było miasto rosną koszty transportu, a zatem intensywność produkcji rolniczej jest malejącą funkcją odległości gospodarstwa od rynku zbytu, czyli miasta. Ekonomia przestrzenna w swoich początkach rozwijała się wśród ekonomistów niemieckich, którzy badali zagadnienia zapoczątkowane przez Thünena. Należy tu wymienić takich ekonomistów jak: Launhardta (1885), który rozwinął i opisał matematycznie ujęcie teorii lokalizacji, Hottelinga (1929) który był twórcą modeli lokalizacji, Webera (1929), który w odróżnieniu od Thünena zajmował się modelami lokalizacji przemysłu oraz i Löscha (1961), który był twórcą teorii rdzenia i peryferii. Spoza szkoły niemieckiej nie można zapomnieć o wkładzie w ekonomię przestrzenną takich ekonomistów jak Isarda (1949), Hoovera (1939) i Ponsarda (1983), którzy zebrali i przedstawili cztery paradygmaty ekonomii przestrzennej. Teorie lokalizacji rozwijane przez ekonomistów niemieckich utraciły swoje znaczenie ze względu na rozwój rynków zbytu, a także zjawisko globalizacji, jednak zagadnienie ekonomii przestrzennej jest rozwijane i zauważane przez ekonomistów. Należy tu wspomnieć o nobliście P. Krugmanie (Fujita i in., 2002), który ustanowił nowy nurt w ekonomii określany jako nową geografię ekonomiczną (NEG). Niewątpliwie na uwzględnienie przestrzeni w ekonomii wpływają możliwości związane $\mathrm{z}$ rozwojem informatyki, a tym samym ekonometrii przestrzennej, za prekursora której można uznać Paelincka i Klaassena (1979), którzy twierdzili, że badane obiekty przestrzenne jakimi są regiony czy państwa podlegają wpływom innych sąsiadujących obiektów przestrzennych oraz zależą od zachodzących w nich procesów ekonomicznych, politycznych i społecznych. Paelinck i Klaassen sformułowali również pięć zasad konstrukcji modeli przestrzennych oraz twierdzili, że w badaniach przestrzennych należy wziąć pod uwagę: współzależność przestrzenną zmiennych endogenicznych, asymetrię i heterogeniczność relacji w przestrzeni oraz odmienne interakcje ex ante i ex post. Poza tym zwrócili oni uwagę na charakterystyki 
przestrzeni zawierające współrzędne obszarów oraz miary odległości i natężenia dla badanych zmiennych. Ekonometria przestrzenna uwzględnia zatem aspekt położenia obiektu w przestrzeni w odróżnieniu od zwykłej ekonometrii, która zajmuje się ustalaniem za pomoca metod matematyczno - statystycznych ilościowych prawidłowości w życiu gospodarczym w aspekcie punktowym lub czasowym (Pietrzykowski, 2011). Lista ekonomistów i ekonometryków, którzy rozwijali zagadnienia przestrzeni w ekonomii jest bardzo długa i należy tu wymienić następujących naukowców: Anselin (1988, 2010), Florax, Rey (Anselin i in., 2004), Hsiao (2003), Getis, Mur, Zoller (Getis i in., 2004), Beltagi (2005), Kopczewska (2006), Suchecki (2010, 2012) i wielu innych.

\section{Dane i metody}

W pracy wykorzystano ogólnodostępne dane statystyczne dotyczące gospodarstw rolnych, a pochodzące z Rachunków Ekonomicznych dla Rolnictwa (RER), z bazy Eurostat. Dane zawarte w Regionalnych Rachunkach Ekonomicznych dla Rolnictwa (RRER) posłużyły do prowadzenia analiz regionalnych. Okres prowadzonych badań zawierał się w latach 2004 - 2013 co pozwoliło między innymi na określenie zmian zachodzących w nowych państwach Unii Europejskiej UE-11 (Estonia, Czechy, Łotwa, Litwa, Polska, Słowacja, Słowenia, Węgry, Bułgaria, Rumunia i Chorwacja). W niniejszej pracy analizę prowadzono na poziomie państw (NUTS-1), ponieważ chciano wykazać istnienie czasowo-przestrzennych zmian $\mathrm{w}$ dochodach gospodarstw rolnych dla państw Unii Europejskiej.

Jedną z podstawowych miar autokorelacji przestrzennych jest współczynnik Morana. Opisuje on zależności pomiędzy sąsiadującymi obiektami. Dlatego w celu określenia zachodzących zmian przestrzennych wykorzystano globalny współczynnik Morana $(\mathrm{R} m)$, który można zapisać następującą formułą:

$$
R m=\frac{N}{\sum_{i=1}^{N} \sum_{j}^{N} w_{i j}} \cdot \frac{\sum_{i=1}^{N} \sum_{j}^{N} w_{i j}\left(x_{i}-\bar{x}\right)\left(x_{j}-\bar{x}\right)}{\sum_{i=1}^{N}\left(x_{i}-\bar{x}\right)^{2}}
$$

gdzie:

$w_{i j} \quad$ - jest konkretnym element macierzy wag

$x_{i} \quad$-jest wartością cechy obiektu w lokalizacji i-tej

$x_{j} \quad-$ jest wartością cechy obiektu w lokalizacji j-tej

$\bar{x} \quad-$ jest przeciętną wartością cechy dla wszystkich badanych obiektów przestrzennych

$N$ - jest liczebnością wszystkich obiektów objętych badaniem przestrzennym

Globalny współczynnik Morana zapisany formułą 1 może być traktowany jako miernik grupowania jednostek w przestrzeni. Należy zauważyć, że współczynnik autokorelacji Morana został zbudowany w oparciu o koncepcję współczynnika korelacji Pearsona oraz statystykę gamma, dzięki której następuje łączenie informacji o podobieństwach obiektów w przestrzeni. Całość informacji dotycząca położenia obiektów w przestrzeni i ich wzajemnych interakcjach zawarta jest w macierzy wag W (Sang-Il 2001). Wykorzystując globalny współczynnik autokorelacji Morana można weryfikować 
hipotezę o braku autokorelacji przestrzennej zakładając, że ma on rozkład asymptotycznie normalny co można przedstawić w celu uproszczenia zapisu w postaci macierzowej jako:

$$
\begin{gathered}
R m=\frac{N}{N_{0}} \cdot \frac{\mathbf{z} \prime \boldsymbol{W z}}{\mathbf{z} \prime \mathbf{z}} \\
Z(R m)=\frac{R m-E(R m)}{\sqrt{\operatorname{var}(R m)}} \sim N(0,1)
\end{gathered}
$$

gdzie:

$$
\begin{array}{ll}
\boldsymbol{z} & - \text { jest wektorem o elementach } z_{i}=x_{i}-\bar{x} \\
N_{0} & - \text { jest sumą wszystkich elementów macierzy } \mathbf{W}
\end{array}
$$

Weryfikację hipotezy o braku autokorelacji przestrzennej przeprowadza się w oparciu o statystykę Z(Rm) (formuła 3), przyjmując, że w przypadku braku autokorelacji przestrzennej współczynnik korelacji Morana $\mathrm{R} m$ ma tendencje do przyjmowania wartości $\mathrm{R} m \approx \mathrm{E}(\mathrm{R} m)$, a $\mathrm{Z}(\mathrm{R} m) \approx 0$.

Korelacje przestrzenne można również przedstawić na wykresie punktowym, który nazywany jest diagramem Morana (rys. 1).

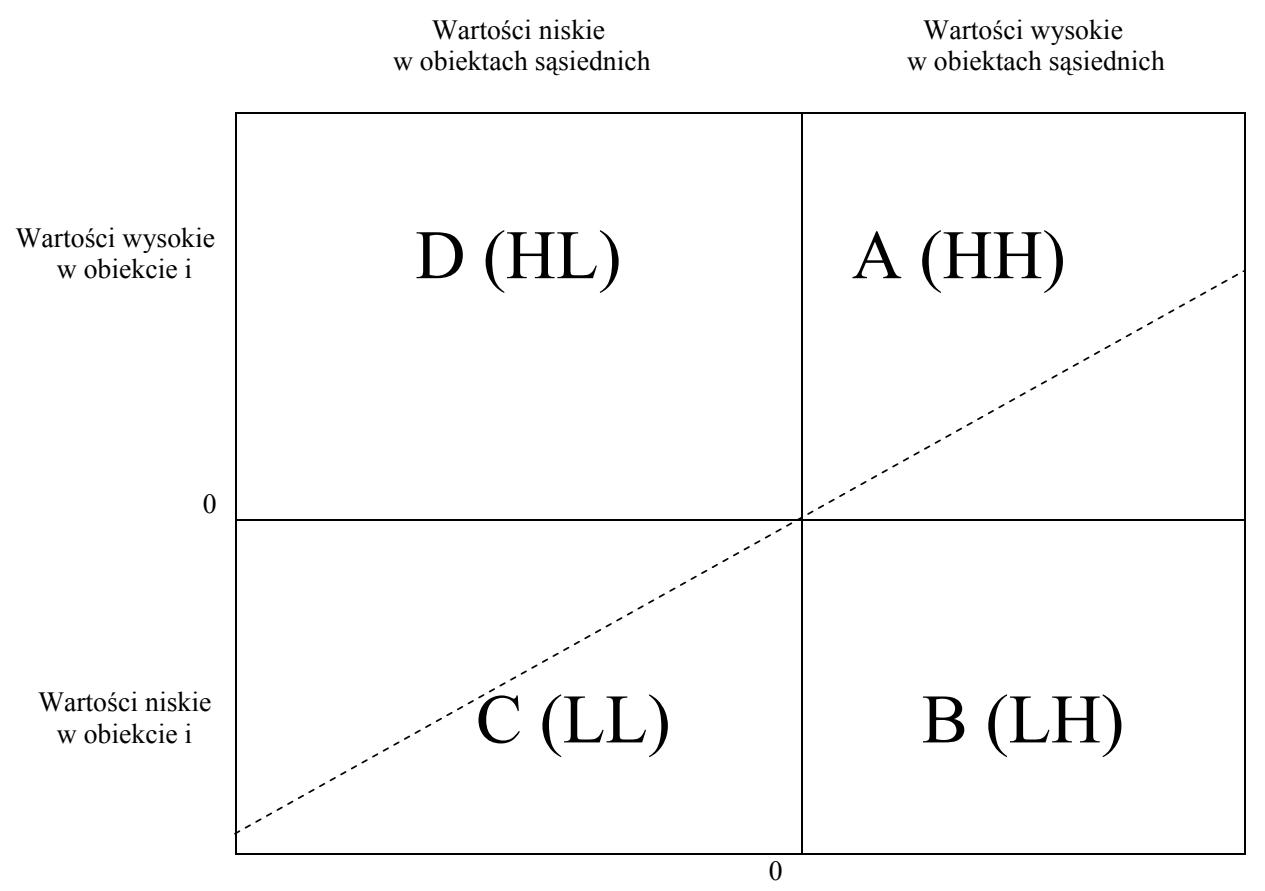

Rys. 1. Zależności przestrzenne na przykładowym wykresie punktowym Morana

Fig.1. Sample graph of Moran's spatial correlation

Źródło: opracowanie własne w oparciu o Kopczewska (Kopczewska, 2007). 
Diagram Morana jest wykresem punktowym. Jest on wykorzystywany do wizualizacji związków przestrzennych, ale również daje możliwość określenia klastrów dla badanych obiektów. Na obu osiach wykresu Morana mamy zmienne standaryzowane. Na osi pionowej odłożona jest standaryzowana zmienna opóźniona przestrzennie $\mathrm{Y}$, a na osi poziomej mamy standaryzowaną zmienną X, która podlega badaniu. Wykres dzieli się na cztery części (ćwiartki). Na rysunku 1 oznaczone jako A, B, C i D. Litery L i H oznaczają odpowiednio Low i Hight. Jeżeli badane obserwacje układają się w części A (HH) oznacza to, że wartości badanej zmiennej w ramach obserwowanych obiektów tworzą klaster. Ze względu na przestrzenny charakter badania mamy zatem do czynienia z państwami, które są podobne ze względu na badaną cechę. W przypadku kiedy występują w ćwiartce A $(\mathrm{HH})$ oznacza to również, że badane państwa są otoczone przez państwa o wysokich wartościach ze względu na badaną cechę. Analogicznie jeżeli państwa znalazły się w ćwiartce C oznacza to, że tworzą klaster, w którym badana cecha przyjmuje wartości niskie dla danego państwa i jego sąsiadów. Przerywana linia na rysunku 1 określa rodzaj korelacji przestrzennej. Jeżeli przebiega ona przez ćwiartki C i A oznacza to autokorelację dodatnią, a kiedy przebiega ona przez ćwiartki D i B autokorelację ujemna. Wartość współczynnika kierunkowego dla tej prostej jest współczynnikiem autokorelacji Morana ( $\mathrm{R} m$ formuła 1). Równomierne rozłożenie państw we wszystkich ćwiartkach możemy traktować jako informację o braku autokorelacji przestrzennej. Efekt dodatniej korelacji można interpretować w następujący sposób: badane państwa skupiają się w przestrzeni i tworzą klastry. W przypadku autokorelacji ujemnej mówimy, że badane państwa różnią się między sobą (,efekt szachownicy”).

Korzystając $\mathrm{z}$ wykresu Morana możemy określić klastry dla badanych państw ze względu na przestrzeń $\mathrm{w}$ jakiej się znajdują. W prowadzonych badaniach wprowadzono efekt czasu dla określenia zmiany w poszczególnych latach porównując współczynnik Morana w latach 2005-2013 oraz rozmieszczenie poszczególnych państw na wykresie Morana. W efekcie tak przeprowadzonych analiz uwzględniono zarówno efekt czasu, jak i przestrzeni $\mathrm{w}$ dochodzie gospodarstw rolniczych. Utrzymanie na podobnym poziomie korelacji przestrzennej (autokorelacji Morana) daje informacje ze względu na badaną cechę uwzględniając jej zróżnicowanie $\mathrm{w}$ czasie i przestrzeni w poszczególnych państwach. Prowadzone analizy zaprezentowano również wizualizując diagramy Morana na mapie administracyjnej Europy.

\section{Wyniki}

Analizując dochody gospodarstw rolniczych dla państw należących do Unii Europejskiej, obliczono współczynniki korelacji Morana dla poszczególnych lat w okresie od 2004 do 2013 roku. Wszystkie współczynniki korelacji okazały się istotne statystycznie. Na rysunku 2 przedstawiono zależności przestrzenne na wykresie punktowym Morana dla roku 2005. Zgodnie z wcześniejszym opisem (patrz rys. 1) przerywane linie przebiegające w punktach 0 obu osi dzieląc wykres na cztery części (ćwiartki). Na osi poziomej mamy odłożoną standaryzowaną wartość dochodu w gospodarstwie rolniczym. Na osi pionowej mamy opóźnienie przestrzenne. Nachylenie ciagłej linii na rysunku 2 określa rodzaj korelacji przestrzennej, która w tym przypadku jest dodatnia. Zaobserwowany efekt dodatniej autokorelacji można zatem interpretować jako występowanie skupień dla badanych państw $\mathrm{w}$ przestrzeni. Zauważmy również, że największe skupiska państw 
(klastry) występują w pierwszej i trzeciej ćwiartce (odpowiednio A i C rys. 1). Państwa, które znajdują się w pierwszej ćwiartce tworzą klaster o którym możemy powiedzieć, że zawiera państwa charakteryzujące się wysokim dochodem gospodarstw rolniczych. Poza tym sąsiadują one z państwami, które również, mają wysokie dochody w gospodarstwach rolniczych. Natomiast państwa znajdujące się w trzeciej ćwiartce w odróżnieniu od państw z ćwiartki pierwszej mają mały dochód i sąsiadują z państwami o niskim dochodzie w gospodarstwach rolniczych. Zauważmy, że klaster państw w ćwiartce pierwszej to państwa „starej” Unii, a w ćwiartce trzeciej znajdują się państwa, które określa się jako „nowe” (UE-11). Prowadzone analizy zaprezentowano również wizualizując diagramy Morana na mapie administracyjnej Europy. Takie przedstawienie analizowanych państw daje bardziej czytelny opis badanego zjawiska (rys. 3).

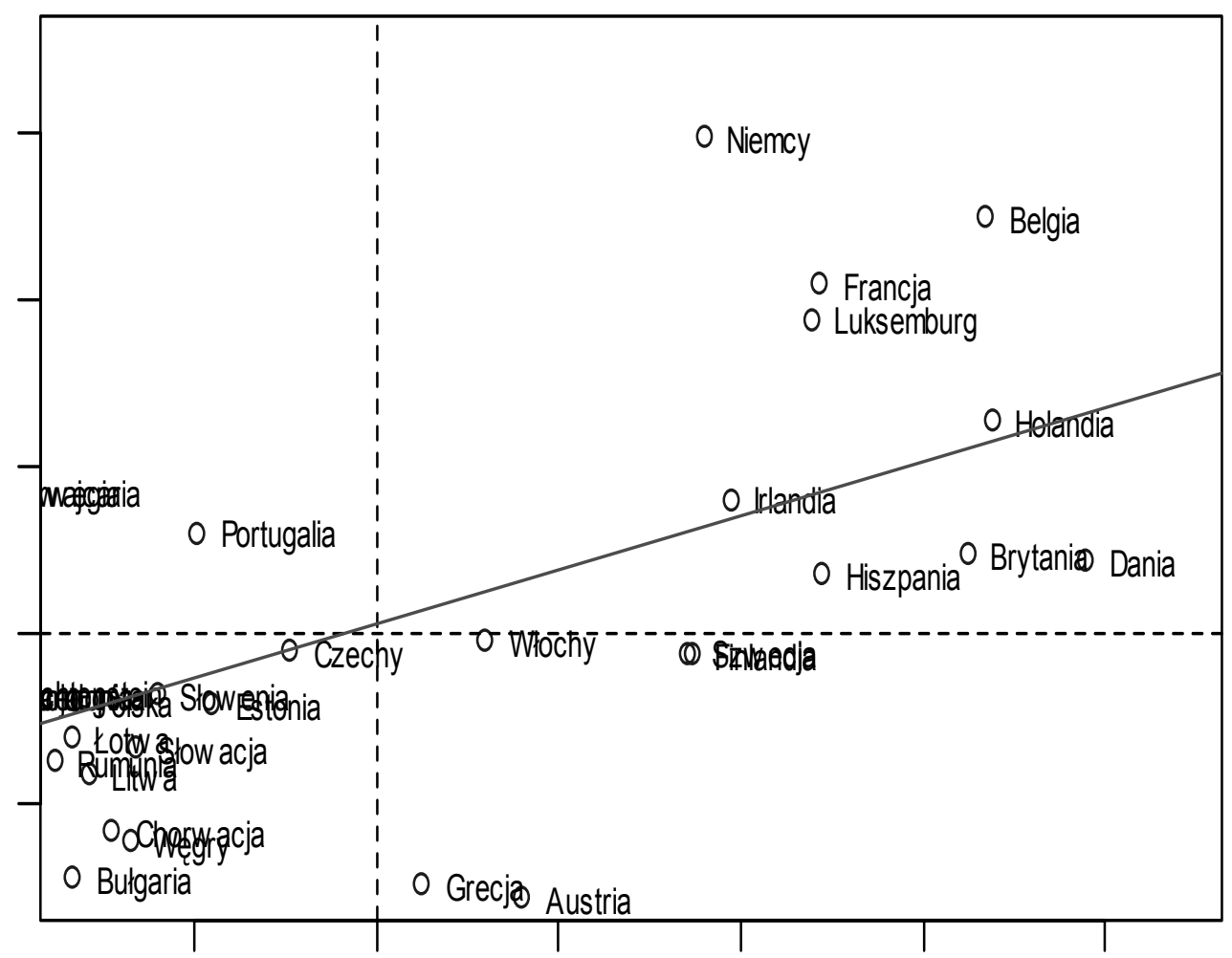

Rys. 2. Diagram Morana dla dochodu gospodarstw rolniczych w państwach UE w roku 2005

Fig. 2. The diagram of correlation Moran of income for agricultural farms in the EU in 2005

Źródło: opracowanie własne na podstawie RER z bazy Eurostat.

Następnie przeprowadzono identyczne obliczenia dla pozostałych lat tzn. dla okresu od 2006 do 2013, uzyskując bardzo podobne wyniki. Utrzymanie na podobnym poziomie korelacji przestrzennej (autokorelacji Morana) w poszczególnych latach daje zatem informacje ze względu na badaną cechę uwzględniając jej zróżnicowanie w czasie i przestrzeni w poszczególnych państwach. Na rysunku 4 przedstawiono zmiany 
współczynnika korelacji Morana w okresie od 2005 do 2013 roku. Wszystkie współczynniki korelacji Morana są istotne i wykazują na dodatnią korelację. Można zatem powiedzieć, że dochody gospodarstw rolniczych w badanych państwach tworzą wyraźne klastry, czyli ich grupowanie charakteryzuje się wyraźną prawidłowością. Poza tym wykazano, że występujące klastry charakteryzują się podziałem wskazującym na grupowanie państw o niskich dochodach z niskimi i wysokich z wysokimi. Można jednak zauważyć, że po roku 2008 ta tendencja została osłabiona, wynika to z coraz mniejszych wartości współczynnika korelacji przestrzennej Morana w badanym okresie. Zauważmy również, że ta tendencja rozpoczęła się w okresie kryzysu światowego i wtedy obserwujemy spadek współczynnika korelacji Morana, co może wskazywać na osłabienie struktury klastrów państw wchodzących w skład Unii Europejskiej.

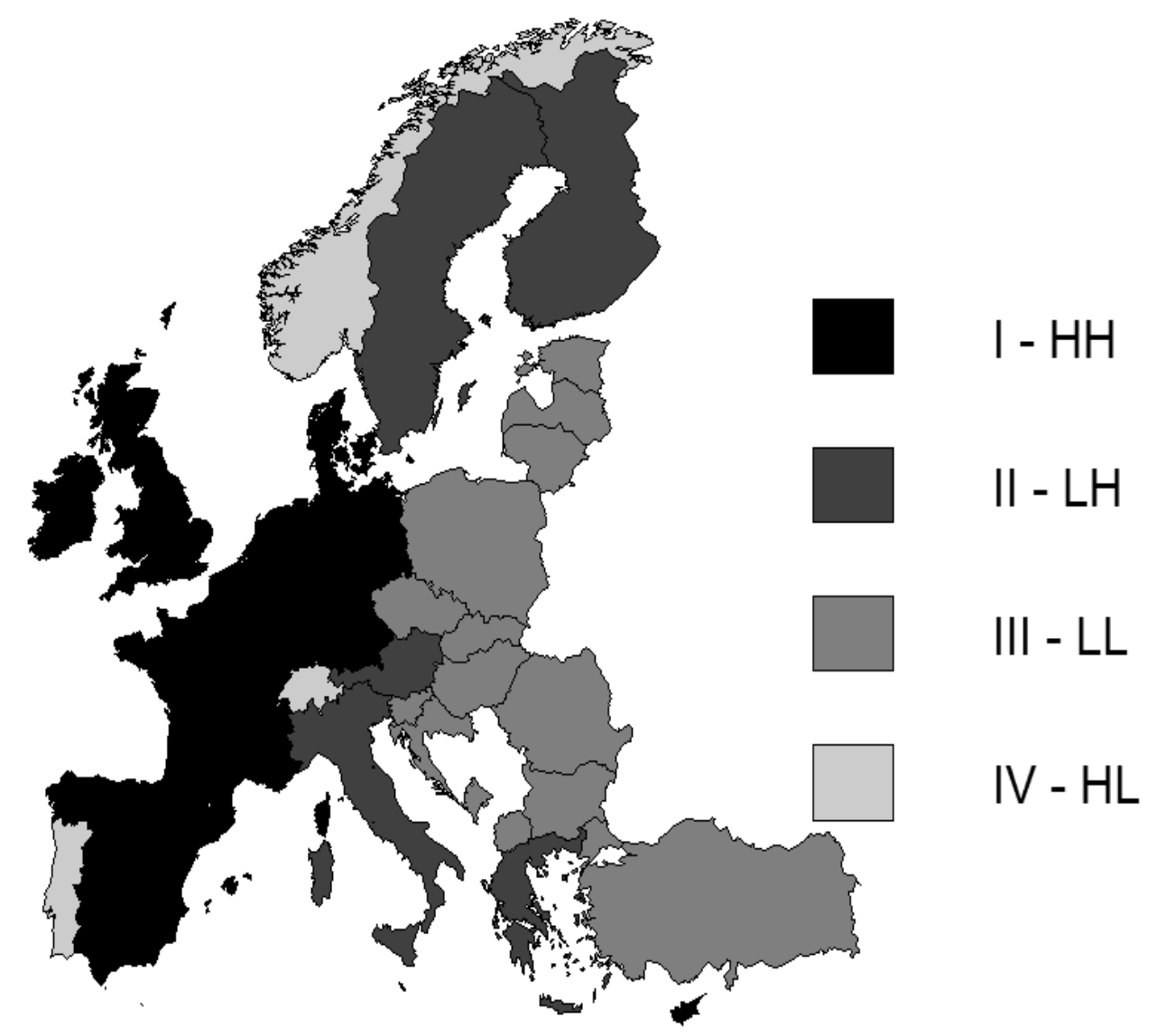

Rys. 3. Wizualizacja podziału państw na cztery klastry związane z ich umiejscowieniem na diagramie Morana w roku 2005

Fig. 3. Visualization of the division of countries into four clusters related to their position on the diagram of Moran in 2005

Źródło: opracowanie własne na podstawie RER z bazy Eurostat. 


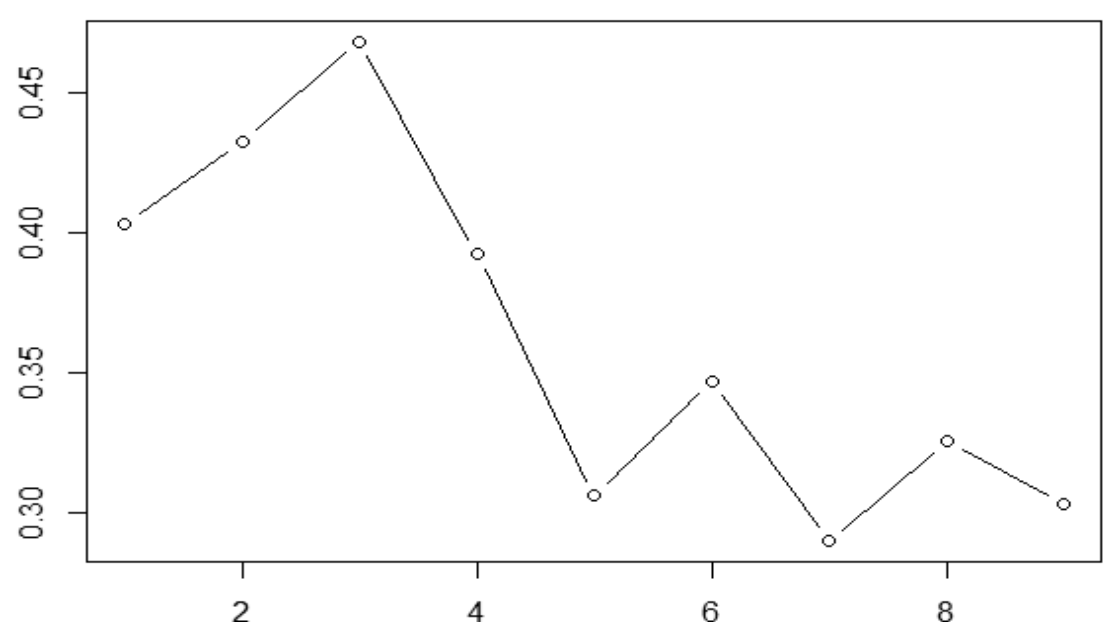

Rys. 4. Zmiany współczynnika korelacji Morana w latach 2005 - 2013

Fig. 4 Changes of correlation coefficient Moran in the years 2005 - 2013

Źródło: opracowanie własne na podstawie RER z bazy Eurostat.

\section{Podsumowanie}

W wyniku przeprowadzonych analiz możemy stwierdzić, że zastosowanie współczynnika autokorelacji Morana pozwoliło na ujęcie badanego zjawiska w przestrzeni, a porównanie jego wartości w badanym okresie uwzględniło drugi czynnik jakim był czas. Uzyskanie dodatniej autokorelacji przestrzennej w całym badanym okresie potwierdziło występowanie klastrów dla państw wchodzących w skład Unii Europejskiej. Stwierdzono również zróżnicowanie pomiędzy państwami Unii Europejskiej oznaczanymi jako UE-15 a nowymi państwami, które wstąpiły do Unii po roku 2004. W wyniku przeprowadzonych analiz stwierdzono, że dochody gospodarstw rolniczych w badanych państwach tworzą wyraźne klastry, czyli ich grupowanie charakteryzuje się wyraźną prawidłowością. Można powiedzieć, że państwa członkowskie „starej” Unii tworzą klastry państw o dochodach wysokich z wysokimi, a państwa nowe tworzą klastry charakteryzujące się podziałem wskazującym na grupowanie państw o niskich dochodach z niskimi. Stwierdzono również, że po roku 2008 ta tendencja została osłabiona, co może wskazywać na osłabienie struktury klastrów państw, czyli słabszym wpływie jednostek sąsiadujących na siebie.

Chociaż państwa „nowe”, które wstąpiły w szeregi Unii Europejskiej (oznaczane jako UE-11) różnią się pod względem dochodów uzyskiwanych z rolnictwa to jednak obserwuje się osłabiania klastrów, czyli tzw. efekt doganiania „starych” państw Unii Europejskiej. Pewnym mankamentem $\mathrm{w}$ prowadzonych analizach jest kwestia występujących agregacji, które wynikają z porównania różnej wielkości gospodarstw, rodzaju kierunków produkcji, regionalizacji i etc. Dlatego wydaje się zasadne przeprowadzenie podobnych badań na jak najniższym poziomie agregacji uwzględniając regionalne zależności przestrzenne oraz ich zmiany w czasie. 


\section{Literatura}

Anselin, L. (1988). Spatial econometrics: Methods and models. Dordrecht: Kluwer Academic.

Anselin, L. (2010). Thirty years of spatial econometrics. Papers in Regional Science, Volume 89, Issue 1.

Anselin, L., Florax, R., Rey, S. (red.), (2004). Advanced in Spatial Econometrics. Methodology. Tools and applications. Springer-Verlag, Berlin.

Baltagi, B.H. (2005). Econometrics analysis of panel data. John Wiley \& Sons. New York.

Biczykowski, M. (2013). Przestrzenna alokacja wsparcia finansowego z instrumentów Wspólnej Polityki Rolnej i ich wpływ na rozwój społeczno-gospodarczy obszarów wiejskich. Acta Universitatis Lodziensis, Folia Geographica Socio-Oeconomica, 13, 93-114.

Czaja, S. (2011). Czas w ekonomii, Wydawnictwo Uniwersytetu Ekonomicznego we Wrocławiu.

Czyżewski, A. (2007). Uniwersalizm polityki rolnej w gospodarce rynkowej: ujęcie makro- i mikroekonomiczne, Wydawnictwo Akademii Ekonomicznej w Poznaniu.

Faber, M. (1986). Studies in Austrian Capital Theory. Investment and Time, Springer-Verlag, Heidelberg.

Fujita, M., Krugman, P., Venables, A.J., (2002). The Spatial Economy: Cities, Regions, and International Trade, The M.I.T. Press, Cambridge, MA

Getis, A., Mur, J., Zoller, H. (red.), (2004). Spatial Econometrics and Spatial Statistics. Palgrave Macmillan, New York.

Hotelling, H. (1929). Stability in Competition. Economic Journal, 39 (153): 41-57.

Hsiao, C., (2003). Analysis of Panel Data. Cambridge University Press.

Hoover, E.M. (1937). Spatial Price Discrimination, Review of Economic Studies, 4.

Isard, W., (1949). The General Theory of Location and Space Economy. Quarterly Journal of Economics, 63, 476-506.

Launhardt, W. (1885). Mathematisch Begrundung der Volkswirtschaftslehre Leipzig: B. G. Teubner, (translated by $\mathrm{H}$. Schmidt and edited and introduction by J. Creedy as Mathematical Principles of Economics. Aldershot: Edward Elgar. 1993)

Lösch, A., (1961). Gospodarka przestrzenna, teoria lokalizacji - Państwowe Wydawnictwo Ekonomiczne, Warszawa.

Kopczewska, K. (2006). Ekonometria i statystyka przestrzenna z wykorzystaniem programu R CRAN, CeDeWu. Warszawa.

Paelinck, J., Klaassen, L. (1979). Spatial econometrics. Farnborough: Saxon House.

Pietrzykowski, R. (2011). Wykorzystanie metod statystycznej analizy przestrzennej w badaniach ekonomicznych, Roczniki Ekonomiczne Kujawsko-Pomorskiej Szkoły Wyższej w Bydgoszczy, nr 4, 97-112.

Pietrzykowski, R., (2016). Analiza zmian wsparcia finansowego Wspólnej Polityki Rolnej w latach 1973-2014, Studia i Prace WNEiZ US, nr 45, t. 2, 397-408.

Pietrzykowski, R., (2016). Makroekonomiczne zmiany w dochodach gospodarstw rolniczych w wybranych krajach Unii Europejskiej, Roczniki Naukowe SERiA, T. 18, z. 5, 206-211.

Ponsard, C. (1983). History of Spatial Economic Theory, Berlin: Springer Verlag, (Benjamin H Steven, Margaret Chevillier and Joaquin P. Pujol, translated).

Sang-Il, L. (2001). Developing a bivariate spatial association measure: An integrationof Pearson's r and Moran's I. Journal of Geographical System, vol. 3, 369-385.

Suchecki, B. (2010). Ekonometria przestrzenna. Metody i modele analizy danych przestrzennych, C.H. Beck, Warszawa.

Suchecki, B. (2012). Ekonometria przestrzenna II. Modele zaawansowane, C.H. Beck, Warszawa.

von Thunen, J.H., (1826). Der Isolierte Staat in Beziehung auf Landtschaft und Nationalokonomie. Hamburg (English Translation by C.M. Wartenberg, von Thunen's Isolated State. Oxford: Pergamon Press, 1966).

Weber, A. (1929). Theory of the Location of Industries. Chicago: The University of Chicago Press (translated by Carl J. Friedrich from Weber's 1909 book).

Zamagni, S., Agliardi, E. (2005). Time in Economic Theory, Edward Elgar Publishing, New York. 